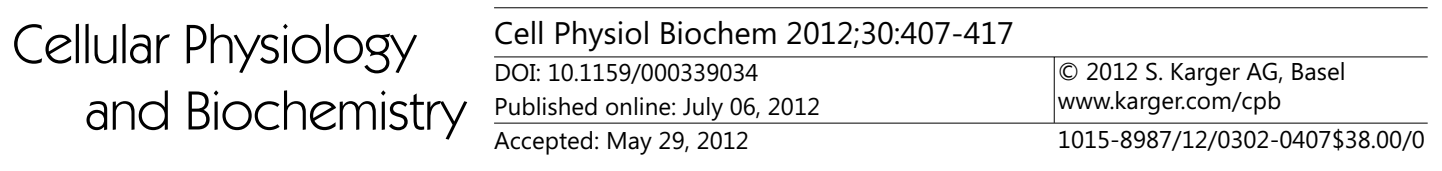

\title{
Effect of Casein Kinase $1 \alpha$ Activator Pyrvinium Pamoate on Erythrocyte Ion Channels
}

\author{
Yuliya Kucherenko ${ }^{1,2 *}$ Christine Zelenak ${ }^{1 *}$ Matthias Eberhard ${ }^{1}$ Syed M. Qadri ${ }^{1}$ \\ Florian Lang ${ }^{1}$
}

${ }^{1}$ Department of Physiology, University of Tübingen, ${ }^{2}$ Institute for Problems of Cryobiology and Cryomedicine of the Ukrainian National Academy of Sciences, Kharkov, ${ }^{*}$ contributed equally and thus share first authorship

\section{Key Words}

$\mathrm{Ca}^{2+}$-permeable cation channels $\cdot \mathrm{Ca}^{2+}$-activated $\mathrm{K}^{+}$channels $\cdot$ Casein kinase $1 \alpha \cdot$ Eryptosis $\bullet$ Erythrocytes $\bullet$ Phosphatidylserine $\cdot$ Annexin $\bullet$ Cell volume

\begin{abstract}
Pharmacological modification of protein kinase CK1 (casein kinase 1) has previously been shown to influence suicidal erythrocyte death or eryptosis, which is triggered by activation of $\mathrm{Cl}^{-}$-sensitive $\mathrm{Ca}^{2+}$-permeable cation channels. $\mathrm{Ca}^{2+}$ entering through those channels stimulates cell membrane scrambling and opens $\mathrm{Ca}^{2+}$-activated $\mathrm{K}^{+}$-channels resulting in $\mathrm{KCl}$ exit and thus cell shrinkage. The specific CK1-inhibitor D4476 $(1 \mu \mathrm{M})$ blunted, whereas the specific CK1 $\alpha$ activator pyrvinium pamoate $(10 \mu \mathrm{M})$ enhanced cell membrane scrambling. The substances were at least partially effective through modification of cytosolic $\mathrm{Ca}^{2+}$-activity. The present study explored, whether pyrvinium pamoate indeed influences $\mathrm{Cl}^{-}$-sensitive cation-channels in erythrocytes. As a result, removal of $\mathrm{Cl}^{-}$increased Fluo3-fluorescence (reflecting cytosolic $\mathrm{Ca}^{2+}$-activity), triggered cell membrane scrambling (apparent from annexin-V-binding), and decreased forward scatter (pointing to cell shrinkage). Pyrvinium pamoate significantly augmented the effect of $\mathrm{Cl}^{-}$-removal on Fluo3 fluorescence and annexin-V-binding, but blunted the effect on forward scatter. According to whole cell patch clamp recording, $\mathrm{Cl}^{-}-$ removal activated a cation current, which was significantly enhanced by pyrvinium pamoate. Pyrvinium pamoate inhibited $\mathrm{Ca}^{2+}$-activated $\mathrm{K}^{+}$-channels. $\mathrm{Ca}^{2+}$-ionophore ionomycin $(1 \mu \mathrm{M})$ decreased forward scatter, an effect significantly blunted by pyrvinium pamoate. In conclusion, pyrvinium pamoate activates $\mathrm{Cl}^{-}$-sensitive $\mathrm{Ca}^{2+}$-permeable cation channels with subsequent $\mathrm{Ca}^{2+}$-entry and inhibits $\mathrm{Ca}^{2+}$-activated $\mathrm{K}^{+}$-channels thus blunting the stimulating effect of $\mathrm{Ca}^{2+}$ on those channels, $\mathrm{K}^{+}$-exit and thus cell shrinkage.
\end{abstract}

Copyright $\odot 2012$ S. Karger AG, Basel 


\begin{tabular}{|c|c|c|}
\hline \multirow{2}{*}{$\begin{array}{l}\text { Cellular Physiology } \\
\text { and Biochemistry }\end{array}$} & \multicolumn{2}{|c|}{ Cell Physiol Biochem 2012;30:407-417 } \\
\hline & $\begin{array}{l}\text { DOI: 10.1159/000339034 } \\
\text { Published online: July 06, } 2012\end{array}$ & $\begin{array}{l}\text { O) } 2012 \text { S. Karger AG, Basel } \\
\text { www.karger.com/cpb }\end{array}$ \\
\hline
\end{tabular}

\section{Introduction}

Erythrocytes may be eliminated by eryptosis, a suicidal cell death characterized by cell shrinkage and cell membrane scrambling [1]. Eryptosis may be triggered by a myriad of xenobiotics and endogenous substances [2-14]. Accelerated eryptosis further contributes to anemia in a variety of clinical disorders [1], such as iron deficiency [15], phosphate depletion [16], Hemolytic Uremic Syndrome [17], sepsis [18], malaria [1, 19, 20] or Wilson's disease [21]. Most xenobiotics and clinical disorders trigger eryptosis mainly by activating $\mathrm{Ca}^{2+}$ permeable cation channels, which are stimulated by removal of $\mathrm{Cl}$, oxidative stress, osmotic shock or prostaglandin $\mathrm{E}_{2}$ [1]. The subsequent $\mathrm{Ca}^{2+}$-entry leads to cell membrane scrambling with phosphatiylserine exposure at the cell surface and to activation of $\mathrm{Ca}^{2+}$-sensitive $\mathrm{K}^{+}$channels with subsequent $\mathrm{K}^{+}$-exit, hyperpolarisation, $\mathrm{Cl}^{-}$-exit and thus cellular $\mathrm{KCl}-$ loss with osmotically obliged exit of water and thus cell shrinkage [1].

According to pharmacological evidence, cellular mechanisms regulating erythrocyte $\mathrm{Ca}^{2+}$-entry and thus eryptosis include the protein kinase CK1 $\alpha$ (casein kinase $1 \alpha$ ) [22], a serine/threonine protein kinase expressed in erythrocytes $[23,24]$ and shown to regulate cytoskeleton proteins $[25,26]$.

In nucleated cells CK1 regulates a variety of cellular functions including membrane trafficking, cell cycle progression, chromosome segregation, apoptosis and cellular differentiation [27, 28]. CK1 phosphorylates $\beta$-catenin and so fosters its degradation [29]. By phosphorylationg RhoB and stress fibers [30], CK1 influences actin stress fiber organization [30]. Furthermore, CK1 participates in four-and-a-half LIM (FHL) signaling [31].

CK1 $\alpha$ is activated by pyrvinium pamoate (6-(Dimethylamino)-2-[2-(2,5-dimethyl1-phenyl-1H-pyrrol-3-yl) ethenyl]-1-methyl-4,4'-methylene-bis [3-hydroxy-2naphthalenecarboxylate] (2:1)-quinolinium) [32], an antimicrobial drug [32-35]. Several CK1 isoforms including CK1 $\alpha$, are inhibited by D4476 (4-(4-(2,3-Dihydrobenzo[1,4]dioxin-6-yl)5-pyridin-2-yl-1H-imidazol-2-yl)benzamide) [36-39], a substance known to either inhibit [40] or foster [37] apoptosis. Most recent experiments revealed that pyrvinium pamoate increases and D4476 inhibits $\mathrm{Ca}^{2+}$-entry into erythrocytes and subsequent eryptosis [22]. Those experiments suggested an effect of pyrvinium pamoate and D4476 on erythrocyte channels. The present study thus explored, whether pyrvinium pamoate modifies the $\mathrm{Cl}^{-}-$ sensitive $\mathrm{Ca}^{2+}$-permeable cation channels in erythrocytes.

\section{Materials and Methods}

Erythrocytes, solutions and chemicals

Leukocyte-depleted erythrocytes from concentrates provided by the blood bank of the University of Tübingen were used. The volunteers providing erythrocytes gave informed consent. The study has been approved by the Ethical commission of the University of Tübingen. For the in vitro experiments on suicidal death of erythrocytes incubations were carried out as indicated in the figure legends at $37^{\circ} \mathrm{C}$ in Ringer solution containing (in mM) $125 \mathrm{NaCl}, 5 \mathrm{KCl}, 1 \mathrm{MgSO}_{4}, 32 \mathrm{~N}$-2-hydroxyethylpiperazine-N-2-ethanesulfonic acid (HEPES), 5 glucose, $1 \mathrm{CaCl}_{2} ; \mathrm{pH} 7.4$ at a hematocrit of $0.4 \%$. Where indicated, $\mathrm{Cl}^{-}$was replaced by gluconate (Sigma, Schnelldorf, Germany). The CK1 inhibitor D4476 (4-(4-(2,3-Dihydrobenzo[1,4]dioxin-6yl)-5-pyridin-2-yl-1H-imidazol-2-yl)benzamide) (Calbiochem, Bad Soden, Germany) and the CK1 $\alpha$ activator pyrvinium pamoate (6-(Dimethylamino)-2-[2-(2,5-dimethyl-1-phenyl-1H-pyrrol-3-yl) ethenyl] -1-methyl4,4'-methylene-bis [3-hydroxy-2-naphthalenecarboxylate] (2:1)-quinolinium) (Sigma, Schnelldorf, Germany) or the Gardos channel inhibitor TRAM 34 [41, 42] (Sigma, Germany) were used at the indicated concentrations.

\section{Phosphatidylserine exposure and forward scatter}

For FACS analysis erythrocytes were washed after incubation once in Ringer solution containing $5 \mathrm{mM} \mathrm{CaCl}_{2}$. The cells were then stained with Annexin-V-FITC (ImmunoTools, Friesoythe, Germany) at a 1:200 dilution. After $15 \mathrm{~min}$, samples were measured by flow cytometric analysis (FACS-Calibur from Becton Dickinson, Heidelberg, Germany). Cells were analysed by forward scatter, and annexin-V-fluorescence intensity 


\section{Cellular Physiology and Biochemistry \\ Cell Physiol Biochem 2012;30:407-417 \\ \begin{tabular}{l|l}
\hline DOI: $10.1159 / 000339034$ & $\begin{array}{l}\text { C 2012 S. Karger AG, Basel } \\
\text { www.karger.com/cpb }\end{array}$ \\
Published online: July 06, 2012 & wwite
\end{tabular} \\ Published online: July 06, 2012}

was measured in fluorescence channel FL-1 with an excitation wavelength of $488 \mathrm{~nm}$ and an emission wavelength of $530 \mathrm{~nm}$.

\section{Measurement of intracellular $\mathrm{Ca}^{2+}$}

After incubation, $50 \mu \mathrm{l}$ suspension of erythrocytes were washed in Ringer solution and then loaded with Fluo-3/AM (Biotium, Hayward, USA) in Ringer solution containing $5 \mathrm{mM} \mathrm{CaCl}_{2}$ and $2 \mu \mathrm{M}$ Fluo-3/AM. The cells were incubated at $37^{\circ} \mathrm{C}$ for $30 \mathrm{~min}$ and then resuspended in $150 \mu \mathrm{l}$ Ringer. The $\mathrm{Ca}^{2+}$-dependent fluorescence intensity was then measured in fluorescence channel FL-1 in FACS analysis. The control cell population (Fluo3-stained cells incubated in normal Ringer solution without any treatment) was set to a geomean of $\sim 20$ arbitary units corresponding to the fluorescence range of $10^{1}-10^{2}$ in the histogram. Alteration of Fluo3-dependent fluorescence intensity was paralleled by the respective shift of the cell population in the histogram. Changes in the geomean (arbitary units) measured by Fluo3-dependent fluorescence were taken as measure of intracellular $\mathrm{Ca}^{2+}$ activity.

\section{Electrophysiology}

Patch clamp recordings were performed at room temperature. The patch electrodes were made of borosilicate glass capillaries (150 TF-10, Clark Medical Instruments) using a horizontal DMZ puller (Zeitz). Pipettes with high resistance from 17 to $23 \mathrm{MOhm}$ were connected via an Ag-AgCl wire to the headstage of an EPC 9 patch-clamp amplifier (HEKA). Data acquisition and data analysis were controlled by a computer equipped with an ITC 16 interface (Instrutech) and by using Pulse software (HEKA). For current measurements, erythrocytes were held at a holding potential $\left(\mathrm{V}_{\mathrm{h}}\right)$ of $-10 \mathrm{mV}$ for the non-selective cation channels and $0 \mathrm{mV}$ for the Gardos channels recordings; $200 \mathrm{~ms}$ pulses from -100 to $+100 \mathrm{mV}$ were applied in increments of $+20 \mathrm{mV}$. The original current traces are depicted without filtering (acquisition frequency of $3 \mathrm{kHz}$ ). The currents were analyzed by averaging the current values measured between 90 and $190 \mathrm{~ms}$ of each square pulse (current- voltage relationship). The applied voltages refer to the cytoplasmic face of the membrane with respect to the extracellular space. The offset potentials between both electrodes were zeroed before sealing. The liquid junction potentials between bath and pipette solutions, and between the bath solutions and the salt bridge (filled with $\mathrm{NaCl}$ bath solution) were calculated according to Barry and Lynch [43]. Data were corrected for liquid junction potentials.

For whole cell recording, the pipette solutions consisted of (in $\mathrm{mM}$ ): $125 \mathrm{Na}$-gluconate, $10 \mathrm{NaCl}, 1$ $\mathrm{MgCl}_{2}, 1 \mathrm{MgATP}, 1 \mathrm{EGTA}, 10 \mathrm{HEPES} / \mathrm{NaOH}$ (pH 7.4) or $120 \mathrm{~K}$-gluconate, $5 \mathrm{KCl}, 1.2 \mathrm{MgCl}_{2}, 2 \mathrm{MgATP}, 2$ EGTA, $2.05 \mathrm{CaCl}_{2}, 10 \mathrm{HEPES} / \mathrm{NaOH}$ ( $\mathrm{pH} 7.4$ ). The $\mathrm{NaCl}$ Ringer bath solution contained (in $\mathrm{mM}$ ): $145 \mathrm{NaCl}, 5 \mathrm{KCl}$, $2 \mathrm{MgCl}_{2}, 1 \mathrm{CaCl}_{2}, 5$ glucose, $10 \mathrm{HEPES} / \mathrm{NaOH}$ (pH 7.4). In the experiments, where $\mathrm{Cl}^{-}$was substituted with gluconate, the solution contained (in mM): 150 Na-gluconate, 5 glucose, 10 HEPES/NaOH (pH 7.4). The Na-gluconate bath solution used for determination of Gardos channel activity contained in addition $5 \mathrm{mM}$ K-gluconate. The NMDG-Cl bath solution contained (in mM): 180 NMDG, 5 glucose, 10 HEPES (titrated with $\mathrm{HCl}$ to pH 7.4). Chemicals were obtained from Sigma (Germany) and were of the highest grade available. Pyrvinium pamoate $(10 \mu \mathrm{M})$ was added either acutely (whole-cell Gardos channels activity measurements) or the cells were pre-incubated $\left(3-6\right.$ hours, $+37^{\circ} \mathrm{C}$ ) with $10 \mu \mathrm{M}$ pyrvinium pamoate (for whole-cell measurements of the non-selective cation channels).

\section{Statistics}

Data are expressed as arithmetic means \pm SEM, $n$ is the number of batches used. As different erythrocyte batches used in distinct experiments are differently susceptible to stimulators of eryptosis, comparisons were always made with erythrocytes from the same batches. Paired ANOVA with Tukey's test as post-test or paired $t$-test, as appropriate, were used for statistical analysis. In some cases, a normalization of values to control values was made and denoted in the respective graphs. $\mathrm{p}<0.05$ was considered as statistically significant.

\section{Results}

The $\mathrm{Ca}^{2+}$-permeable cation channels are activated by $\mathrm{Cl}^{-}$removal. To activate the channels, $\mathrm{Cl}^{-}$was thus replaced by gluconate. The experiments were performed in the absence and presence of the CK1 inhibitor D4476. In a first series of experiments Fluo3 fluorescence has been utilized to estimate cytosolic $\mathrm{Ca}^{2+}$ activity. In the presence of $\mathrm{Cl}^{-}, 10 \mu \mathrm{M}$ D4476 slightly but 


\section{Cellular Physiology \\ Cell Physiol Biochem 2012;30:407-417 \\ and Biochemistry

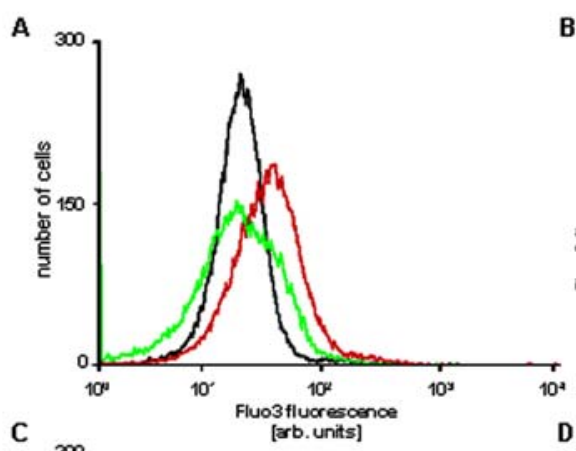

\section{B}
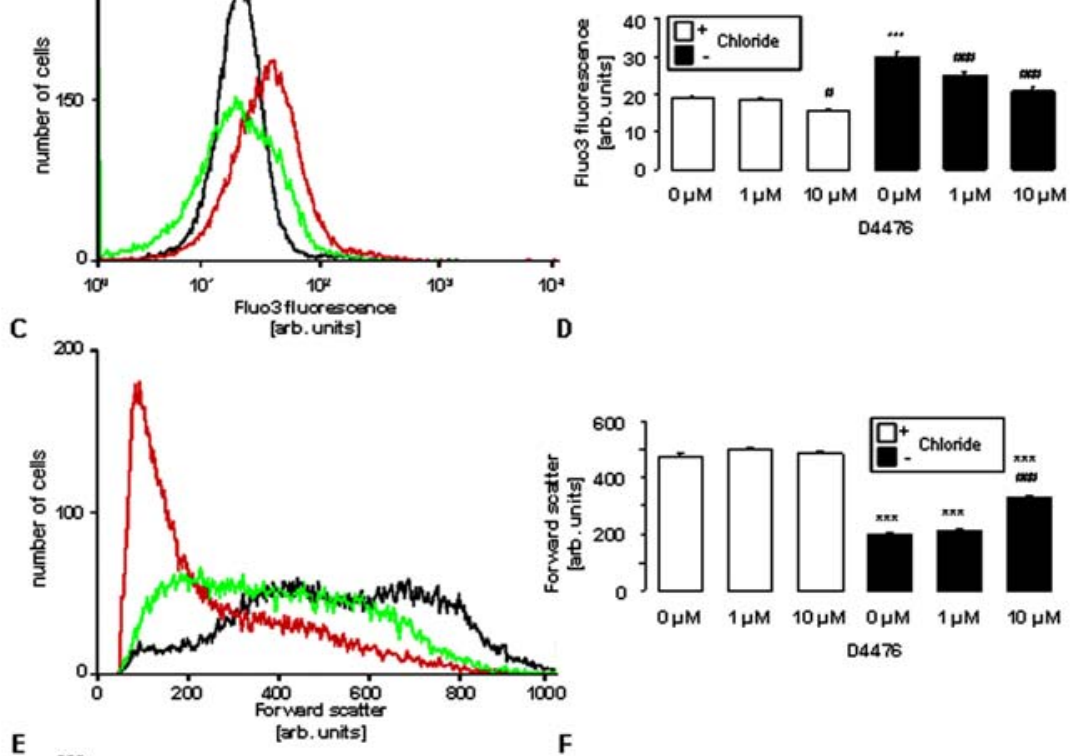

D
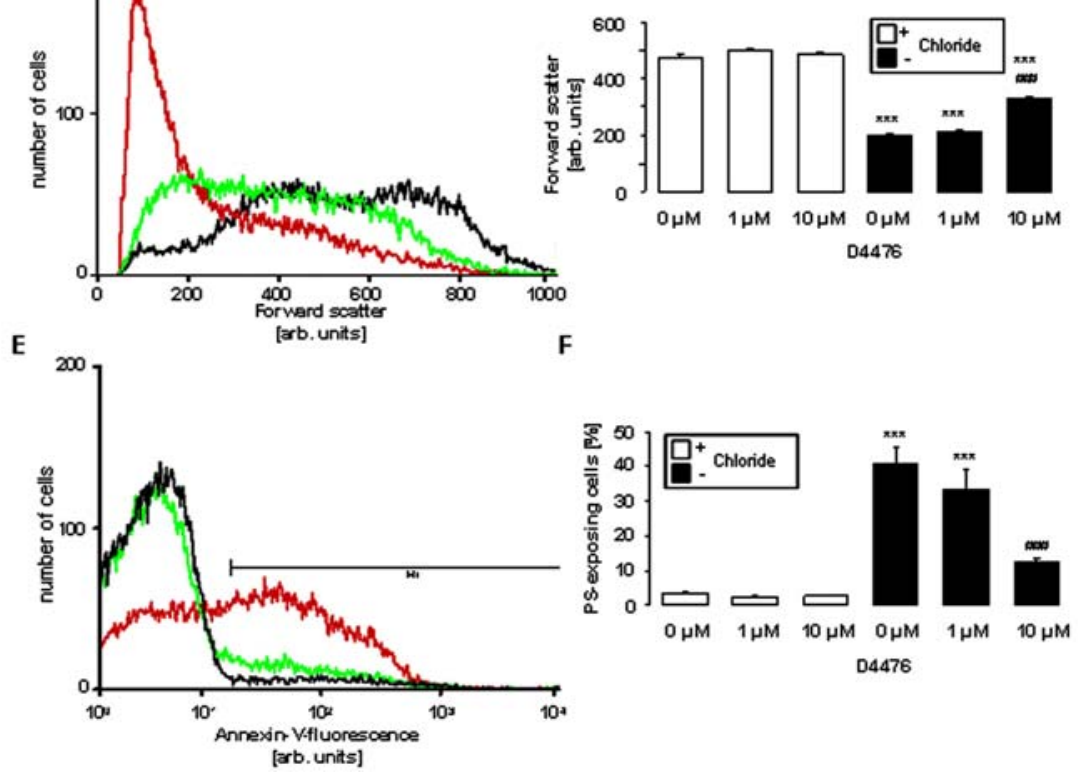

Fig. 1. Effect of D4476 on erythrocyte Fluo3-fluorescence, forward scatter and phosphatidylserine exposure following $\mathrm{Cl}^{-}$removal. A. Histograms of Fluo3-fluorescence reflecting cytosolic $\mathrm{Ca}^{2+}$-activity in representative experiments of erythrocytes exposed for 48 hours to Ringer with (black line) or without $\mathrm{Cl}^{-}$in the absence (red line) or presence (green line) of CK1 inhibitor D4476 $(10 \mu \mathrm{M})$. B. Arithmetic means \pm SEM $(n=7)$ of the of Fluo3-fluorescence in erythrocytes following a 48 hours incubation in the absence or presence of D4476 (1 or $10 \mu \mathrm{M})$. The erythrocytes were exposed 48 hours to $\mathrm{Cl}^{-}$-containing control Ringer (white bars) or Cl-depleted Ringer (black bars) ${ }^{* * *}$ indicate significant $(\mathrm{p}<0.001)$ difference from $\mathrm{Cl}^{-}$containing Ringer,, ,\#\# significant $(\mathrm{p}<0.05, \mathrm{p}<0.001)$ difference from the absence of D4476 (ANOVA). C. Histograms of forward scatter in representative experiments of erythrocytes exposed for 48 hours to Ringer with (black line) or without $\mathrm{Cl}^{-}$in the absence (red line) or presence (green line) of CK1 inhibitor D4476 (10 $\left.\mu \mathrm{M}\right)$. D. Arithmetic means \pm SEM $(n=8)$ of the forward scatter of erythrocytes following a 48 hours incubation in the absence or presence of D4476 $(1$ or $10 \mu \mathrm{M})$. The erythrocytes were exposed 48 hours to $\mathrm{Cl}^{-}$-containing control Ringer (white bars) or $\mathrm{Cl}^{-}$-depleted Ringer (black bars) ${ }^{* * *}$ indicate significant $(\mathrm{p}<0.001)$ difference from $\mathrm{Cl}^{-}$-containing Ringer, \#\#\# indicate significant $(\mathrm{p}<0.001)$ difference from absence of D4476 (ANOVA). E. Histograms of annexin-V-binding reflecting phosphatidylserine exposure in representative experiments of erythrocytes exposed for 48 hours to Ringer with (black line) or without $\mathrm{Cl}^{-}$in the absence (red line) or presence (green line) of CK1 inhibitor D4476 $(10 \mu \mathrm{M})$. F. Arithmetic means \pm SEM $(n=8)$ of the of annexinV-binding of erythrocytes following a 48 hours incubation in the absence or presence of 1 or $10 \mu \mathrm{M}$ D4476. The erythrocytes were exposed 48 hours to $\mathrm{Cl}^{-}$containing control Ringer (white bars) or $\mathrm{Cl}^{-}$depleted Ringer (black bars) ${ }^{* * *}$ indicate significant $(\mathrm{p}<0.001)$ difference from $\mathrm{Cl}^{-}$containing Ringer, ${ }^{\# \#}$ indicate significant $(p<0.001)$ difference from absence of D4476 (ANOVA).

significantly, decreased Fluo3 fluorescence (Fig. 1A,B). $\mathrm{Cl}^{-}$removal was followed by a marked increase of Fluo3 fluorescence (Fig. 1A,B). D4476 blunted the increase of Fluo3-fluorescence following $\mathrm{Cl}^{-}$-removal, an effect reaching statistical significance at $1 \mu \mathrm{M}$ D4476. 


\section{Cellular Physiology \\ Cell Physiol Biochem 2012;30:407-417 \\ and Biochemistry

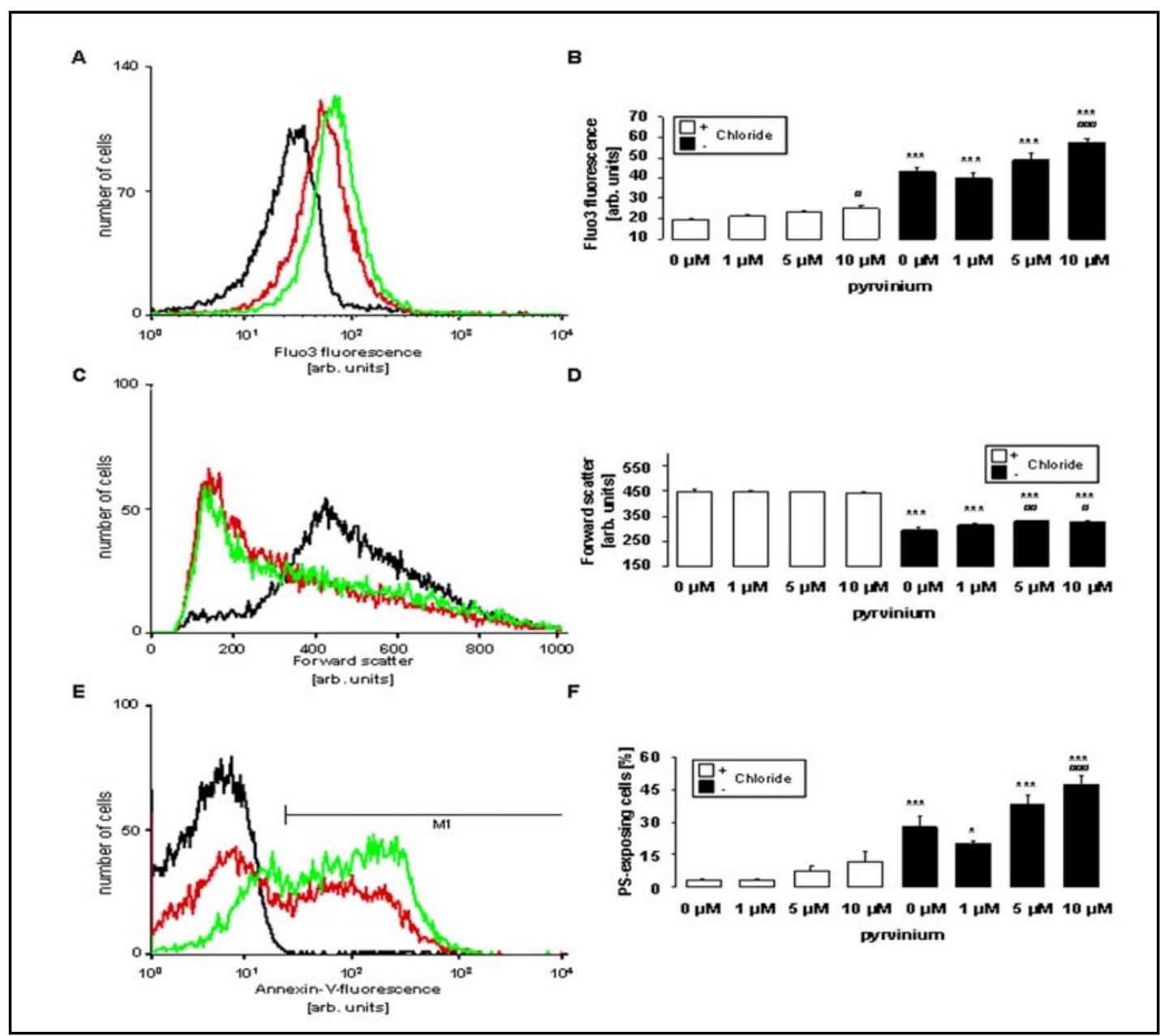

Fig. 2. Effect of pyrvinium pamoate on erythrocyte Fluo3 fluorescence, forward scatter and phosphatidylserine exposure following $\mathrm{Cl}^{-}$removal. A. Histograms of Fluo3 fluorescence reflecting cytosolic $\mathrm{Ca}^{2+}$ activity in representative experiments of erythrocytes exposed for 24 hours to Ringer with (black line) or without $\mathrm{Cl}^{-}$in the absence of CK1 $\alpha$ activator pyrvinium and during additional 24 hours in the absence (red line) or presence (green line) of CK1 $\alpha$ activator pyrvinium pamoate $(10 \mu \mathrm{M})$. B. Arithmetic means \pm SEM ( $n=6-21$ ) of the of Fluo3 fluorescence in erythrocytes following a 24 hours incubation in the absence of pyrvinium pamoate and then further 24 hours in the absence or presence of pyrvinium pamoate $(1,5,10$ $\mu \mathrm{M}$ ). The erythrocytes were exposed 48 hours to $\mathrm{Cl}^{-}$containing control Ringer (white bars) or $\mathrm{Cl}^{-}$depleted Ringer (black bars) ${ }^{* * *}$ indicate significant $(\mathrm{p}<0.001)$ difference from $\mathrm{Cl}^{-}$containing Ringer, \#,\#\# indicate significant $(\mathrm{p}<0.001)$ difference from absence of pyrvinium pamoate (ANOVA). C. Histograms of forward scatter in representative experiments of erythrocytes exposed for 24 hours to Ringer with (black line) or without $\mathrm{Cl}^{-}$in the absence of CK1a activator pyrvinium and during additional 24 hours in the absence (red line) or presence (green line) of CK1 $\alpha$-activator pyrvinium pamoate $(10 \mu \mathrm{M})$. D. Arithmetic means \pm SEM $(n=16)$ of the forward scatter of erythrocytes following a 24 hours incubation in the absence of pyrvinium pamoate and then further 24 hours in the absence or presence of pyrvinium pamoate $(1,5,10 \mu \mathrm{M})$. The erythrocytes were exposed 48 hours to $\mathrm{Cl}^{-}$- containing control Ringer (white bars) or $\mathrm{Cl}^{-}$-depleted Ringer (black bars) ${ }^{* * *}$ indicate significant $(\mathrm{p}<0.001)$ difference from $\mathrm{Cl}^{-}$-containing Ringer. \#\#\# indicate significant $(\mathrm{p}<0.05, \mathrm{p}<0.01)$ difference from the absence of pyrvinium pamoate (ANOVA). E. Histograms of annexinV-binding reflecting phosphatidylserine exposure in representative experiments of erythrocytes exposed for 24 hours to Ringer with (black line) or without $\mathrm{Cl}^{-}$in the absence of CK1 $\alpha$ activator pyrvinium and during additional 24 hours in the absence (red line) or presence (green line) of CK1 $\alpha$ activator pyrvinium pamoate $(10 \mu \mathrm{M})$. F. Arithmetic means \pm SEM $(n=16)$ of the of annexin-V-binding of erythrocytes following a 24 hours incubation in the absence of pyrvinium pamoate and then further 24 hours in the absence or presence of pyrvinium pamoate $(1,5,10 \mu \mathrm{M})$. The erythrocytes were exposed 48 hours to $\mathrm{Cl}^{-}$containing control Ringer (white bars) or $\mathrm{Cl}^{-}$depleted Ringer (black bars) $*, * * *$ indicate significant $(\mathrm{p}<0.05, \mathrm{p}<0.001)$ difference from $\mathrm{Cl}^{-}$-containing Ringer, ${ }^{\# \# \# ~ i n d i c a t e ~ s i g n i f i c a n t ~}(\mathrm{p}<0.001)$ difference from the absence of pyrvinium pamoate (ANOVA). 


\section{Cellular Physiology \\ Cell Physiol Biochem 2012;30:407-417 \\ and Biochemistry

A
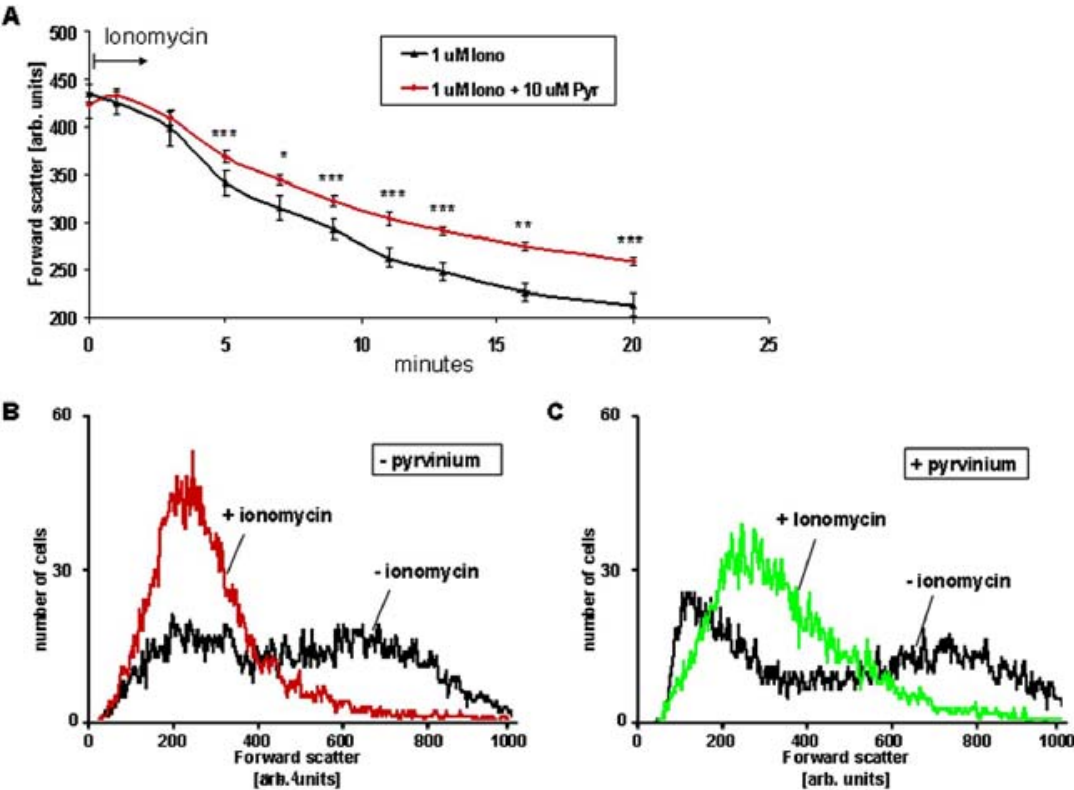

Fig. 3. Effect of pyrvinium pamoate on ionomycin induced decrease of forward scatter. A. Histogram showing the changes in forward scatter induced by ionomycin $(1 \mu \mathrm{M})$ within 11 minutes in absence of pyrvinium pamoate. B. Histogram showing the changes in forward scatter induced by ionomycin $(1 \mu \mathrm{M})$ within 11 minutes in the presence of pyrinium pamoate $(10 \mu \mathrm{M})$. C. Time-dependent decrease of the forward scatter after treatment with ionomycin with (red line) and without (black line) pyrvinium pamoate. ${ }^{* * *}$ indicate significant $(\mathrm{p}<0.001)$ difference from absence of pyrvinium pamoate ( $t$-test).

An increase of cytosolic $\mathrm{Ca}^{2+}$ is expected to activate $\mathrm{Ca}^{2+}$-sensitive $\mathrm{K}^{+}$-channels with subsequent $\mathrm{K}^{+}$-exit, hyperpolarization, $\mathrm{Cl}^{-}$-exit and cell shrinkage. Forward scatter was utilized to estimate cell volume. $\mathrm{Cl}$-removal was followed by a significant decrease of forward scatter (Fig. 1C,D). The addition of the specific CK1 inhibitor D4476 did not significantly alter forward scatter in the presence of $\mathrm{Cl}^{-}$but at $10 \mu \mathrm{M}$ D4476 significantly blunted the decrease of forward scatter following $\mathrm{Cl}^{-}$-removal (Fig. 1C,D).

$\mathrm{Cl}$-removal further triggered cell membrane scrambling with exposure of phosphatidylserine at the erythrocyte surface, which could be quantified by annexin-V-binding. $\mathrm{Cl}$-removal was followed by a significant increase in annexin-V-binding (Fig. 1E,F). Addition of D4476 did not significantly modify annexin-V-binding in the presence of $\mathrm{Cl}$; but blunted the increase of annexin-V-binding following $\mathrm{Cl}-$-removal, an effect reaching statistical significance at $10 \mu \mathrm{M}$ D4476 (Fig. 1E,F).

A further series of experiments explored the effect of the CK1 $\alpha$-activator pyrvinium pamoate. As illustrated in Fig. 2A,B, pyrvinium pamoate $(10 \mu \mathrm{M})$ slightly but significantly increasedFluo3-fluorescencein the presence of Cl. Moreover, pyrvinium pamoate significantly augmented the increase of Fluo3-fluorescence following $\mathrm{Cl}^{-}$removal (Fig. 2A,B), an effect reaching statistical significance at $10 \mu \mathrm{M}$. Pyrvinium pamoate did not significantly alter forward scatter in the presence of $\mathrm{Cl}^{-}$but at 5 and $10 \mu \mathrm{M}$ significantly blunted the decrease of forward scatter following $\mathrm{Cl}^{-}$-removal (Fig. 2C,D). Addition of pyrvinium pamoate tended to increase annexin-V-binding in the presence of $\mathrm{Cl}^{-}$, an effect, however, not reaching statistical significance. Pyrvinium pamoate augmented the increase of annexin-V-binding following $\mathrm{Cl}^{-}$removal, an effect reaching statistical significance at $10 \mu \mathrm{M}$ pyrvinium pamoate (Fig. 2E,F).

The effect of pyrvinium pamoate on Fluo3-fluorescence suggested a stimulating effect of pyrvinium pamoate on $\mathrm{Cl}^{\text {-sensitive }} \mathrm{Ca}^{2+}$-permeable cation channels, the blunting effect of pyrvinium pamoate on the decline of forward scatter following $\mathrm{Cl}^{-}$-removal pointed to an inhibitory effect on $\mathrm{Ca}^{2+}$-activated $\mathrm{K}^{+}$- or $\mathrm{Cl}^{-}$-channels. To further explore the effect of pyrvinium pamoate on cell volume, forward scatter was determined prior to and during 
Fig. 4. Effect of pyrvinium pamoate on $\mathrm{Cl}^{-}$sensitive cation channels. A. Whole-cell current tracings (Na-gluconate pipette and $\mathrm{NaCl}$ Ringer bath solution) recorded in bath Ringer (left), 180 mM NMDG-chloride (middle) and $150 \mathrm{mM}$ Na-gluconate (right) in the absence (upper panel) and presence (lower panel) of $10 \mu \mathrm{M}$ pyrvinium pamoate. B. Arithmetic means $( \pm$ SEM, $n=11$ ) of the whole cell current as a function of voltage (I-V relationship) in erythrocytes containing $150 \mathrm{mM}$ Na-gluconate in the pipette and either Ringer (open triangles), $180 \mathrm{mM}$ NMDG-chloride (closed triangles) or $150 \mathrm{mM}$ Na-gluconate (closed squares) in the absence of pyrvinium pamoate. C. Arithmetic means $( \pm$ SEM, $n=11$ ) of the whole cell current as a function of voltage (I-V relationship) in erythrocytes containing $150 \mathrm{mM} \mathrm{Na-gluconate}$ in the pipette and either Ringer (open triangles), 180 mM NMDGchloride (closed triangles) or $150 \mathrm{mM}$ Na-gluconate (closed squares) in the presence of pyrvinium pamoate $(10 \mu \mathrm{M})$. D. Arithmetic means $( \pm$ SEM, $n=$ 11) of the whole cell conductance (as calculated from the data in $(B, C)$ for the inward currents by linear regression) in erythrocytes containing 150 mM Na-gluconate in the pipette and either Ringer (Ringer), Na-gluconate (NaGlu) or $180 \mathrm{mM}$ NMDG-chloride (NMDG-Cl) in the absence (white bars) or presence (black bars) of pyrvinium pamoate $(10 \mu \mathrm{M})$. E. Arithmetic means $( \pm$ SEM, $n$ $=11$ ) of $\mathrm{Cl}^{-}$-dependent sodium conductance, calculated as a
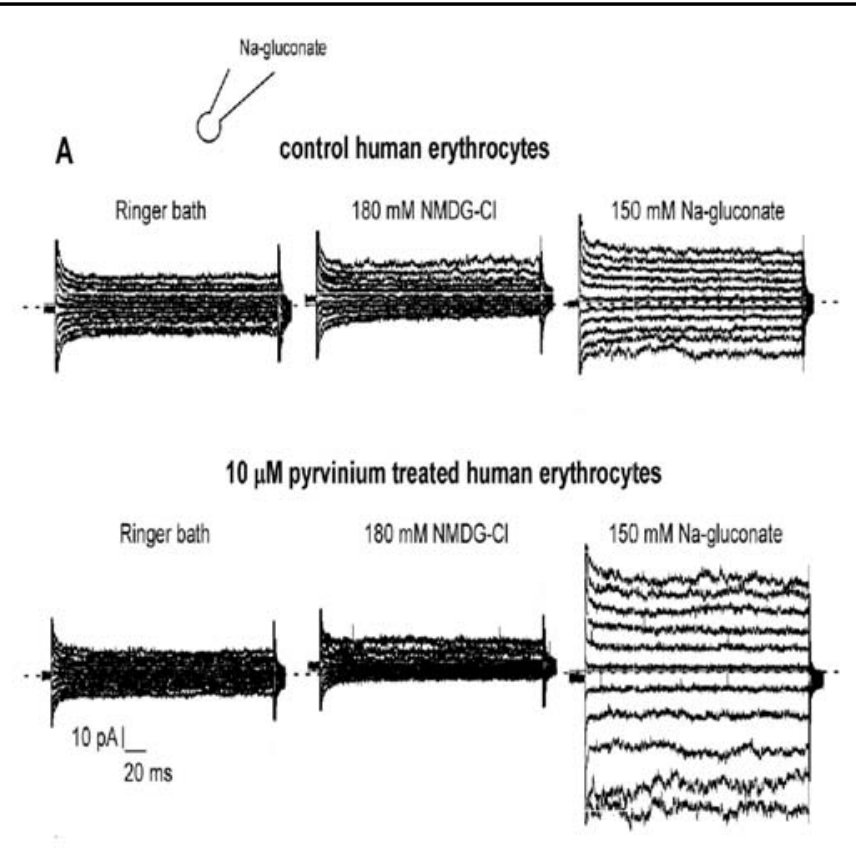

B

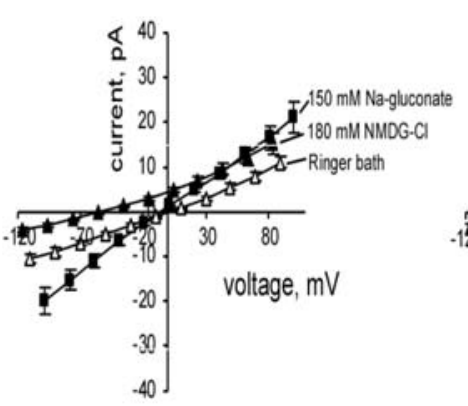

D

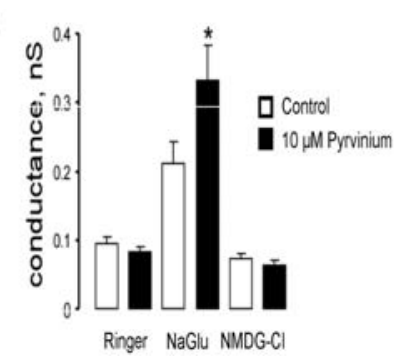

C
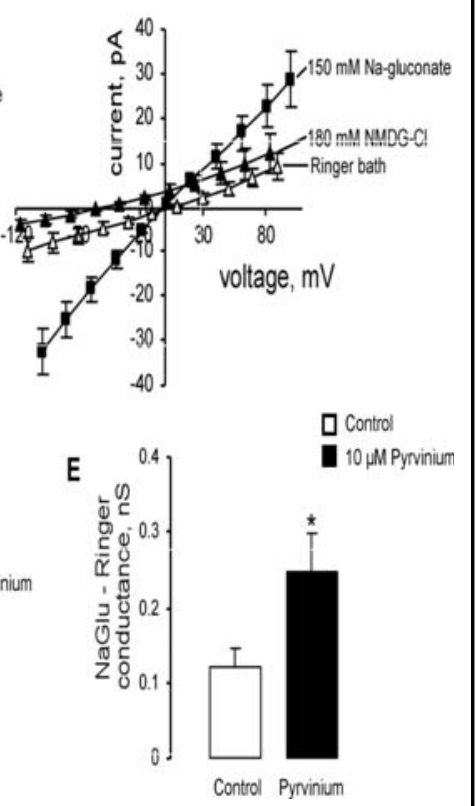

difference of the conductances in Na-gluconate and $\mathrm{NaCl}$ bath media in the bath in the absence (white bar) or presence (black bar) of pyrvinium pamoate $(10 \mu \mathrm{M})$. *indicates significant $(\mathrm{p}<0.05)$ difference from absence of pyrvinium pamoate (t-test).

20 minutes following treatment with the $\mathrm{Ca}^{2+}$-ionophore ionomycin $(1 \mu \mathrm{M})$. As illustrated in Fig. 3, administration of ionomycin was followed by a decline of forward scatter, which was significantly blunted in the presence of $10 \mu \mathrm{M}$ pyrvinium pamoate from 5 minutes onwards.

Whole cell patch clamp was employed to closely define the channels involved in $\mathrm{Ca}^{2+}$ entry and in cell shrinkage. The $\mathrm{Cl}^{-}$-sensitive unspecific $\mathrm{Ca}^{2+}$-permeable cation channels were recorded with Na-gluconate in the pipette and NaCl-Ringer, NMDG-Cl or Na-gluconate in the bath solution. As illustrated in Fig. 4, whole cell currents in the presence of Na-gluconate in the pipette increased by replacement of Ringer with Na-gluconate in the bath, an effect 


\section{Cellular Physiology \\ Cell Physiol Biochem 2012;30:407-417 and Biochemistry

Fig. 5. Effect of pyrvinium pamoate on Gardos channel activity. A. Current tracings (Kgluconate pipette and Na-Kgluconate bath solutions) in the absence of channel inhibitors (left), in the presence of $10 \mu \mathrm{M}$ pyrvinium pamoate (middle) and in the presence of $1 \mu \mathrm{M}$ Gardos channel inhibitor TRAM 34 (right). B. Current-voltage (I-V) relationships (arithmetic means \pm SEM; $n=8$ ) of human erythrocytes recorded with $120 \mathrm{mM}$ K-gluconate pipette solution and Na-K-gluconate bath solution in the absence of inhibitors (closed squares), upon acute application of 10 $\mu \mathrm{M}$ pyrvinium pamoate (open triangles) or in the presence of 1 $\mu \mathrm{M}$ TRAM 34 (closed triangles). C. Normalized $\left(\mathrm{I}_{+80 \mathrm{mV}}\right)$ currentvoltage $(\mathrm{I}-\mathrm{V}) \quad$ relationships (arithmetic means \pm SEM; $\mathrm{n}=8$ ) of human erythrocytes recorded with $120 \mathrm{mM} \mathrm{K}$-gluconate pipette solution and Na-K-gluconate bath solution in the absence of inhibitors (open squares), upon acute application of 10 $\mu \mathrm{M}$ pyrvinium pamoate (closed triangles) or in the presence of 1 $\mu \mathrm{M}$ TRAM 34 (open diamonds).

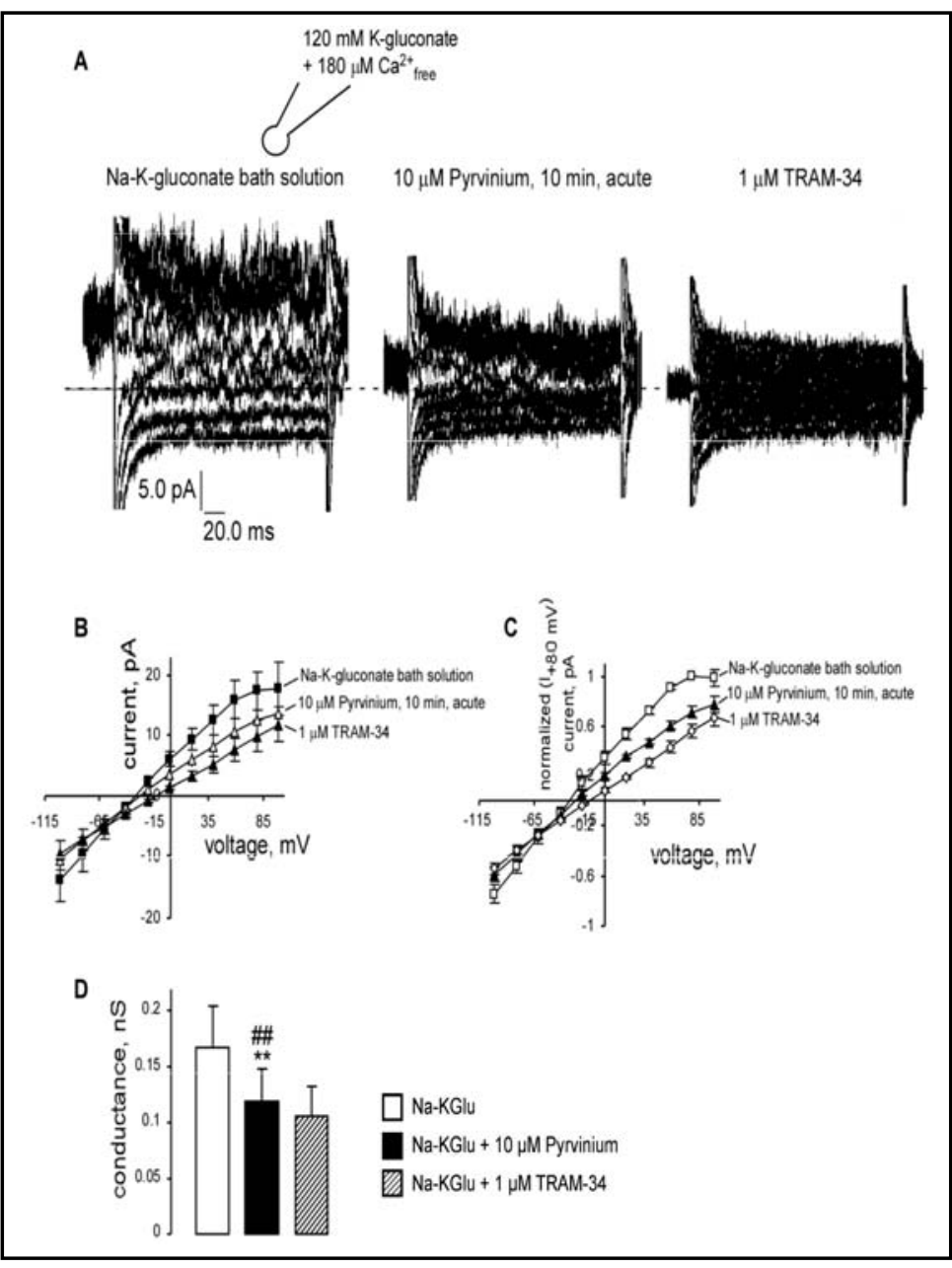
D. Arithmetic means $( \pm S E M, n=8)$ of the whole cell conductance in erythrocytes recorded with K-gluconate in the pipette and Na-K-gluconate in the bath solutions (as calculated for the linear part of I-V dependences between $+20 \mathrm{mV}$ and $+60 \mathrm{mV}$ ) in the absence of inhibitors (white bar), in the presence of $10 \mu \mathrm{M}$ pyrvinium pamoate (black bar) or in the presence of $1 \mu \mathrm{M}$ TRAM 34 (stippled bar). *indicates significant $(\mathrm{p}<0.05)$ difference from absence of pyrvinium pamoate (paired t-test).

augmented in the cells exposed to pyrvinium pamoate $(10 \mu \mathrm{M}$, after 3 - 6 hours incubation at $37^{\circ} \mathrm{C}$ ).

The inhibition of $\mathrm{Ca}^{2+}$-induced cell shrinkage by pyrvinium pamoate could, at least in theory, result from inhibition of the $\mathrm{Ca}^{2+}$-activated (Gardos) $\mathrm{K}^{+}$-channels, which are sensitive to the channel inhibitor TRAM $34(1 \mu \mathrm{M})$. Whole-cell patch clamp experiments with $\mathrm{K}$ gluconate pipette solution confirmed the presence of TRAM 34 sensitive $\mathrm{Ca}^{2+}$-activated $\mathrm{K}^{+}$channels with characteristics similar to Gardos channels (Fig. 5).The Gardos channels activity was stimulated by addition of $\mathrm{CaCl}_{2}\left(180 \mu \mathrm{M}\right.$ intracellular free $\left.\mathrm{Ca}^{2+}\right)$ to the $\mathrm{K}$-gluconate pipette bath solution. Acute application of pyrvinium pamoate $(10 \mu \mathrm{M})$ resulted in a significant decline in the Gardos channel activity during the first 10 min of incubation (Fig. 5).

\section{Discussion}

The present observations provide the novel evidence that the casein kinase $1 \alpha$ (CK1 $\alpha$ ) activator pyrvinium pamoate [32] stimulates the $\mathrm{Cl}^{-}$-sensitive $\mathrm{Ca}^{2+}$-cation channel and by the same token inhibits the $\mathrm{Ca}^{2+}$-activated $\mathrm{K}^{+}$-channel in erythrocytes. Accordingly, pyrvinium pamoate augments the increase in Fluo3-fluorescence and blunts the decrease of forward 


\section{Cellular Physiology and Biochemistry

\author{
Cell Physiol Biochem 2012;30:407-417 \\ \begin{tabular}{l|l}
\hline DOI: $10.1159 / 000339034$ & C 2012 S. Karger AG, Basel
\end{tabular} \\ Published online: July 06, $2012 \quad$ www.karger.com/cpb
} \\ Kucherenko/Zelenak/Eberhard/Qadri/Lang: Pyrvinium Sensitive Erythrocyte Channels}

scatter following $\mathrm{Cl}^{-}$removal. Inhibition of CK1 $\alpha$ with the specific CK1 inhibitor D4476 [36, 39] blunts the increase of Fluo3-fluorescence following $\mathrm{Cl}^{-}$-removal, an observation supporting the view that the effect of pyrvinium pamoate on the $\mathrm{Cl}^{-}$-sensitive $\mathrm{Ca}^{2+}$-permeable cation channel is at least partially due to activation of CK1 $\alpha$. The activation of the channel leads to the expected stimulation of cell membrane scrambling, an effect again blunted by D4476 and augmented by pyrvinium pamoate. Similar to pyrvinium pamoate, D4476 blunts the effect of $\mathrm{Cl}-$-removal on forward scatter. Thus, the inhibitory effect of pyrvinium pamoate on the $\mathrm{Ca}^{2+}$ activated $\mathrm{K}^{+}$-channels is presumably not related to its stimulating effect on CK1 $\alpha$.

Apparently, in the presence of $\mathrm{Cl}^{-}$the activity of the $\mathrm{Cl}^{-}$-sensitive $\mathrm{Ca}^{2+}$-permeable cation channel is low and the $\mathrm{Ca}^{2+}$ entry through this channel is negligible. Under those conditions, inhibition of CK1 with D4476 decreased Fluo3-fluorescence with no effect on forward scatter and annexin-V-binding. Pyrvinium pamoate, on the other hand, increased Fluo3-fluorescence significantly in the presence and absence of $\mathrm{Cl}^{-}$. It did not increase cell membrane scrambling in the presence of $\mathrm{Cl}$, but significantly enhanced cell membrane scrambling following $\mathrm{Cl}^{-}$ -removal. Thus, the effects of D4476 and pyrvinium pamoate on eryptosis become only apparent, when the $\mathrm{Cl}^{-}$-sensitive $\mathrm{Ca}^{2+}$-permeable cation channel is activated by $\mathrm{Cl}^{-}$-removal. Along those lines, CK1 activity may not be relevant for erythrocyte survival under conditions, when the channel is not activated by oxidative stress or energy depletion, as under those conditions, CK1 inhibition is without appreciable effect on cell membrane scrambling [22]. Instead, activated CK1 $\alpha$ augments cell membrane scrambling following glucose depletion and oxidative stress.

At least in theory, CK1 may play a similar role in nucleated cells. A role of CK1 in the regulation of cell survival has been reported before, but considered to be due to interference with transcriptional regulation [37, 39] and modification of $\beta$-catenin [29]. Those mechanisms are not likely to participate in the effect of CK1 on cell membrane scrambling, as erythrocytes are devoid of nuclei and the transcriptional or translational machinery.

The effect of CK1 on the cell survival could involve other protein kinases linked to and activated by CK1. CK1 was shown to phosphorylate PKC $[44,45]$ and PKC in turn phosphorylates CK1 [46]. PKC is known to regulate several TRP channels [47-51]. Moreover, PKC up-regulates endothelin-1 receptors coupled to TRPC1/5/6 channels [51], which participate in the erythrocyte cation channels [52]. In addition, endogenous PKC was shown to modulate the Gardos channels activity in human erythrocytes [53].

In conclusion, the present observations disclose that CK1 $\alpha$ stimulator pyrvinium pamoate is a positive regulator of the $\mathrm{Cl}^{-}$-sensitive $\mathrm{Ca}^{2+}$-permeable cation channel, and thus of $\mathrm{Ca}^{2+}$ entry and cell membrane scrambling in erythrocytes.

\section{Acknowledgements}

The authors acknowledge the valuable imput of Boris Macek, the friendly support by Mehrdad Ghashghaeinia and the meticulous preparation of the manuscript by Tanja Loch and Sari Rübe. This study was supported by the Deutsche Forschungsgemeinschaft, GRK 1302, SFB 773, La 315/13-3.

\section{References}

1 Foller M, Bobbala D, Koka S, Huber SM, Gulbins E, Lang F: Suicide for survival-death of infected erythrocytes as a host mechanism to survive malaria. Cell Physiol Biochem 2009;24:133-140.

2 Bhavsar SK, Gu S, Bobbala D, Lang F: Janus kinase 3 is expressed in erythrocytes, phosphorylated upon energy depletion and involved in the regulation of suicidal erythrocyte death. Cell Physiol Biochem 2011;27:547556. 


\section{Cellular Physiology and Biochemistry \\ Cell Physiol Biochem 2012;30:407-417

\begin{tabular}{|c|c|}
\hline DOI: 10.1159/000339034 & (C) 2012 S. Karger AG, Base \\
\hline
\end{tabular} \\ www.karger.com/cpb}

3 Felder KM, Hoelzle K, Ritzmann M, Kilchling T, Schiele D, Heinritzi K, Groebel K, Hoelzle LE: Hemotrophic mycoplasmas induce programmed cell death in red blood cells. Cell Physiol Biochem 2011;27:557-564.

$4 \quad$ Gatidis S, Zelenak C, Fajol A, Lang E, Jilani K, Michael D, Qadri SM, Lang F: p38 MAPK Activation and Function following Osmotic Shock of Erythrocytes. Cell Physiol Biochem 2011;28:1279-1286.

5 Ghashghaeinia M, Toulany M, Saki M, Bobbala D, Fehrenbacher B, Rupec R, Rodemann HP, Ghoreschi K, Rocken M, Schaller M, Lang F, Wieder T: The NFkB pathway inhibitors Bay 11-7082 and parthenolide induce programmed cell death in anucleated Erythrocytes. Cell Physiol Biochem 2011;27:45-54.

6 Lang E, Jilani K, Zelenak C, Pasham V, Bobbala D, Qadri SM, Lang F: Stimulation of suicidal erythrocyte death by benzethonium. Cell Physiol Biochem 2011;28:347-354.

7 Nguyen DB, Wagner-Britz L, Maia S, Steffen P, Wagner C, Kaestner L, Bernhardt I: Regulation of phosphatidylserine exposure in red blood cells. Cell Physiol Biochem 2011;28:847-856.

8 Qadri SM, Bauer J, Zelenak C, Mahmud H, Kucherenko Y, Lee SH, Ferlinz K, Lang F: Sphingosine but not sphingosine-1-phosphate stimulates suicidal erythrocyte death. Cell Physiol Biochem 2011;28:339-346.

9 Qadri SM, Kucherenko Y, Zelenak C, Jilani K, Lang E, Lang F: Dicoumarol Activates Ca-permeable Cation Channels Triggering Erythrocyte Cell Membrane Scrambling. Cell Physiol Biochem 2011;28:857-864.

10 Bhavsar SK, Eberhard M, Bobbala D, Lang F: Monensin induced suicidal erythrocyte death. Cell Physiol Biochem 2010;25:745-752.

11 Bobbala D, Alesutan I, Foller M, Huber SM, Lang F: Effect of anandamide in Plasmodium Berghei-infected mice. Cell Physiol Biochem 2010;26:355-362.

12 Eberhard M, Ferlinz K, Alizzi K, Cacciato PM, Faggio C, Foller M, Lang F: FTY720-induced suicidal erythrocyte death. Cell Physiol Biochem 2010;26:761-766.

13 Lang F, Gulbins E, Lang PA, Zappulla D, Foller M: Ceramide in suicidal death of erythrocytes. Cell Physiol Biochem 2010;26:21-28.

14 Siraskar B, Ballal A, Bobbala D, Foller M, Lang F: Effect of amphotericin B on parasitemia and survival of plasmodium berghei-infected mice. Cell Physiol Biochem 2010;26:347-354.

15 Kempe DS, Lang PA, Duranton C, Akel A, Lang KS, Huber SM, Wieder T, Lang F: Enhanced programmed cell death of iron-deficient erythrocytes. FASEB J 2006;20:368-370.

16 Birka C, Lang PA, Kempe DS, Hoefling L, Tanneur V, Duranton C, Nammi S, Henke G, Myssina S, Krikov M, Huber SM, Wieder T, Lang F: Enhanced susceptibility to erythrocyte "apoptosis" following phosphate depletion. Pflugers Arch 2004;448:471-477.

17 Lang PA, Beringer O, Nicolay JP, Amon O, Kempe DS, Hermle T, Attanasio P, Akel A, Schafer R, Friedrich B, Risler T, Baur M, Olbricht CJ, Zimmerhackl LB, Zipfel PF, Wieder T, Lang F: Suicidal death of erythrocytes in recurrent hemolytic uremic syndrome. J Mol Med 2006;84:378-388.

18 Kempe DS, Akel A, Lang PA, Hermle T, Biswas R, Muresanu J, Friedrich B, Dreischer P, Wolz C, Schumacher U, Peschel A, Gotz F, Doring G, Wieder T, Gulbins E, Lang F: Suicidal erythrocyte death in sepsis. J Mol Med 2007;85:269-277.

19 Koka S, Bobbala D, Lang C, Boini KM, Huber SM, Lang F: Influence of paclitaxel on parasitemia and survival of Plasmodium berghei infected mice. Cell Physiol Biochem 2009;23:191-198.

20 Lang PA, Kasinathan RS, Brand VB, Duranton C, Lang C, Koka S, Shumilina E, Kempe DS, Tanneur V, Akel A, Lang KS, Foller M, Kun JF, Kremsner PG, Wesselborg S, Laufer S, Clemen CS, Herr C, Noegel AA, Wieder T, Gulbins E, Lang F, Huber SM: Accelerated clearance of Plasmodium-infected erythrocytes in sickle cell trait and annexin-A7 deficiency. Cell Physiol Biochem 2009;24:415-428.

21 Lang PA, Schenck M, Nicolay JP, Becker JU, Kempe DS, Lupescu A, Koka S, Eisele K, Klarl BA, Rubben H, Schmid KW, Mann K, Hildenbrand S, Hefter H, Huber SM, Wieder T, Erhardt A, Haussinger D, Gulbins E, Lang F: Liver cell death and anemia in Wilson disease involve acid sphingomyelinase and ceramide. Nat Med 2007;13:164170.

22 Zelenak C, Eberhard M, Jilani K, Qadri SM, Macek B, Lang F: Protein kinase CK1a regulates erythrocyte survival. Cell Physiol Biochem 2012;in press.

23 Hosey MM, Tao M: Protein kinases of rabbit and human erythrocyte membranes. Solubilization and characterization. Biochim Biophys Acta 1977;482:348-357.

24 Zelenak C, Foller M, Velic A, Krug K, Qadri SM, Viollet B, Lang F, Macek B: Proteome analysis of erythrocytes lacking AMP-activated protein kinase reveals a role of PAK2 kinase in eryptosis. J Proteome Res 2011;10:16901697.

25 Brockman JL, Anderson RA: Casein kinase I is regulated by phosphatidylinositol 4,5-bisphosphate in native membranes. J Biol Chem 1991;266:2508-2512.

26 Manno S, Takakuwa Y, Nagao K, Mohandas N: Modulation of erythrocyte membrane mechanical function by beta-spectrin phosphorylation and dephosphorylation. J Biol Chem 1995;270:5659-5665.

27 Knippschild U, Wolff S, Giamas G, Brockschmidt C, Wittau M, Wurl PU, Eismann T, Stoter M: The role of the casein kinase 1 (CK1) family in different signaling pathways linked to cancer development. Onkologie 2005;28:508-514.

28 Knippschild U, Gocht A, Wolff S, Huber N, Lohler J, Stoter M: The casein kinase 1 family: participation in multiple cellular processes in eukaryotes. Cell Signal 2005;17:675-689. 


\section{Cellular Physiology and Biochemistry \\ Cell Physiol Biochem 2012;30:407-417

\begin{tabular}{l|l}
\hline DOI: $10.1159 / 000339034$ & C 2012 S. Karger AG, Basel \\
www.karger.com/cpb
\end{tabular} \\ www.karger.com/cpb}

29 Sinnberg T, Menzel M, Kaesler S, Biedermann T, Sauer B, Nahnsen S, Schwarz M, Garbe C, Schittek B: Suppression of casein kinase 1 alpha in melanoma cells induces a switch in beta-catenin signaling to promote metastasis. Cancer Res 2010;70:6999-7009.

30 Tillement V, Lajoie-Mazenc I, Casanova A, Froment C, Penary M, Tovar D, Marquez R, Monsarrat B, Favre G, Pradines A: Phosphorylation of RhoB by CK1 impedes actin stress fiber organization and epidermal growth factor receptor stabilization. Exp Cell Res 2008;314:2811-2821.

31 Ding L, Wang Z, Yan J, Yang X, Liu A, Qiu W, Zhu J, Han J, Zhang H, Lin J, Cheng L, Qin X, Niu C, Yuan B, Wang X, Zhu C, Zhou Y, Li J, Song H, Huang C, Ye Q: Human four-and-a-half LIM family members suppress tumor cell growth through a TGF-beta-like signaling pathway. J Clin Invest 2009;119:349-361.

32 Thorne CA, Hanson AJ, Schneider J, Tahinci E, Orton D, Cselenyi CS, Jernigan KK, Meyers KC, Hang BI, Waterson AG, Kim K, Melancon B, Ghidu VP, Sulikowski GA, LaFleur B, Salic A, Lee LA, Miller DM, III, Lee E: Smallmolecule inhibition of Wnt signaling through activation of casein kinase 1alpha. Nat Chem Biol 2010;6:829836.

33 Downey AS, Chong CR, Graczyk TK, Sullivan DJ: Efficacy of pyrvinium pamoate against Cryptosporidium parvum infection in vitro and in a neonatal mouse model. Antimicrob Agents Chemother 2008;52:31063112.

34 Hempelmann E: Hemozoin biocrystallization in Plasmodium falciparum and the antimalarial activity of crystallization inhibitors. Parasitol Res 2007;100:671-676.

35 TURNER JA, JOHNSON PE, Jr: Pyrvinium pamoate in the treatment of pinworm infection (enterobiasis) in the home. J Pediatr 1962;60:243-251.

36 Bain J, Plater L, Elliott M, Shpiro N, Hastie CJ, McLauchlan H, Klevernic I, Arthur JS, Alessi DR, Cohen P: The selectivity of protein kinase inhibitors: a further update. Biochem J 2007;408:297-315.

37 Huart AS, Maclaine NJ, Meek DW, Hupp TR: CK1 alpha plays a central role in mediating MDM2 control of p53 and E2F-1 protein stability. J Biol Chem 2009;284:32384-32394.

38 Maclaine NJ, Hupp TR: The regulation of p53 by phosphorylation: a model for how distinct signals integrate into the p53 pathway. Aging (Albany NY) 2009;1:490-502.

39 Rena G, Bain J, Elliott M, Cohen P: D4476, a cell-permeant inhibitor of CK1, suppresses the site-specific phosphorylation and nuclear exclusion of FOX01a. EMBO Rep 2004;5:60-65.

40 Li C, MacDonald JI, Hryciw T, Meakin SO: Nerve growth factor activation of the TrkA receptor induces cell death, by macropinocytosis, in medulloblastoma Daoy cells. J Neurochem 2010;112:882-899.

41 Grgic I, Kaistha BP, Paschen S, Kaistha A, Busch C, Si H, Kohler K, Elsasser HP, Hoyer J, Kohler R: Disruption of the Gardos channel (KCa3.1) in mice causes subtle erythrocyte macrocytosis and progressive splenomegaly. Pflugers Arch 2009;458:291-302.

42 Tharp DL, Bowles DK: The intermediate-conductance $\mathrm{Ca}^{2+}$-activated $\mathrm{K}^{+}$channel (KCa3.1) in vascular disease. Cardiovasc Hematol Agents Med Chem 2009;7:1-11.

43 Barry PH, Lynch JW: Liquid junction potentials and small cell effects in patch-clamp analysis. J Membr Biol 1991;121:101-117.

44 Okano M, Yokoyama T, Miyanaga T, Ohtsuki K: Activation of C-kinase eta through its cholesterol-3-sulfatedependent phosphorylation by casein kinase I in vitro. Biol Pharm Bull 2004;27:109-112.

45 Vila J, Walker JM, Itarte E, Weber MJ, Sando JJ: Phosphorylation of protein kinase C by casein kinase-1. FEBS Lett 1989;255:205-208.

46 Giamas G, Hirner H, Shoshiashvili L, Grothey A, Gessert S, Kuhl M, Henne-Bruns D, Vorgias CE, Knippschild U: Phosphorylation of CK1delta: identification of Ser370 as the major phosphorylation site targeted by PKA in vitro and in vivo. Biochem J 2007;406:389-398.

47 Adcock JJ: TRPV1 receptors in sensitisation of cough and pain reflexes. Pulm Pharmacol Ther 2009;22:6570 .

48 Earley S, Straub SV, Brayden JE: Protein kinase C regulates vascular myogenic tone through activation of TRPM4. Am J Physiol Heart Circ Physiol 2007;292:H2613-H2622.

49 Harteneck C, Gollasch M: Pharmacological modulation of diacylglycerol-sensitive TRPC3/6/7 channels. Curr Pharm Biotechnol 2011;12:35-41.

50 Peng H, Lewandrowski U, Muller B, Sickmann A, Walz G, Wegierski T: Identification of a Protein Kinase Cdependent phosphorylation site involved in senssitization of TRPV4 channel. Biochem Biophys Res Commun 2010;391:1721-1725.

51 Saleh SN, Albert AP, Large WA: Activation of native TRPC1/C5/C6 channels by endothelin-1 is mediated by both PIP3 and PIP2 in rabbit coronary artery myocytes. J Physiol 2009;587:5361-5375.

52 Foller M, Mahmud H, Gu S, Kucherenko Y, Gehring EM, Shumilina E, Floride E, Sprengel R, Lang F: Modulation of suicidal erythrocyte cation channels by an AMPA antagonist. J Cell Mol Med 2009;13:3680-3686.

53 Del Carlo B, Pellegrini M, Pellegrino M: Modulation of $\mathrm{Ca}^{2+}$-activated $\mathrm{K}^{+}$channels of human erythrocytes by endogenous protein kinase C. Biochim Biophys Acta 2003;1612:107-116. 